\title{
MİKRODALGA DESTEKLİ HİDRODİSTİLASYON YÖNTEMİYLE ELDE EDİLEN PELARGONIUM GRAVEOLENS (ITIR) ESANSIYYEL YAĞININ KARAKTERİSTİK BAZI ÖZELLIKKLERİ
}

\author{
Pelin Aydınlık, Yonca Karagül Yüceer* \\ Çanakkale Onsekiz Mart Üniversitesi, Mühendislik Fakültesi, Gıda Mühendisliği Bölümü, Çanakkale
}

Geliş / Received: 25.04.2021; Kabul / Accepted: 24.06.2021; Online bask1 / Published online: 16.08.2021

Aydınlık, P., Karagül Yüceer, Y. (2021). Mikrodalga destekli hidrodistilasyon yöntemiyle elde edilen Pelargonıum graveolens (Itır) esansiyel yağının karakteristik bazı özellikleri. GIDA (2021) 46 (5) 1117-1131 doi: 10.15237 /gida.GD21076

Aydnllk, P., Karagül Yüceer, Y. (2021). Characteristic some properties of Pelargonum graveolens (Rose-scented geranium) essential oil obtained by microwave-assisted bydrodistilation method. GIDA (2021) 46 (5) 1117-1131 doi: 10.15237/gida.GD21076

ÖZ

Bu çalsşmada Pelargonium graveolens'den (1tır) elde edilen esansiyel yağın karakteristik özellikleri incelenerek doğal katkı maddesi olarak elma suyunda kullanılabilirliği araşıırılmıştır. Esansiyel yağ üretiminde mikrodalga destekli hidrodistilasyon yöntemi kullanılmış ve $\% 1.75$ verimle esansiyel yağ üretimi gerçekleştirilmiştir. Uçucu bileşenlerin tanımlanması amacıyla gaz kromatografisi kütle spektrometresi kullanılmışırı. Itır esansiyel yağının temel uçucu bileşenleri sitronelil format, izomenton, linalol, sitronelol ve geraniol olarak belirlenmiştir. Esansiyel yağın antioksidan aktivitesi $0.54 \mathrm{mM}$ troloks $/ \mathrm{mL}$ yağ bulunmuştur. Esansiyel yağın antibakteriyel etkisinin Escherichia coli'ye kiyasla Staphylococcus aureus üzerine daha fazla olduğu saptanmıstır. Itır esansiyel yağ1 ilave edilmiş elma suyunun mikrobiyel yükünde depolama boyunca düşüş olduğu belirlenmiştir. Ayrıca esansiyel yağ ilave edilen elma suyunun duyusal özellikler bakımından da kabul edilebilir olduğu tüketici testiyle ortaya koyulmuştur.

Anahtar kelimeler: Pelargonium graveolens, 1tır, esansiyel yağ, antioksidan aktivite, antibakteriyel aktivite, duyusal

\section{CHARACTERISTIC SOME PROPERTIES OF PELARGONIUM GRAVEOLENS (ROSE-SCENTED GERANIUM) ESSENTIAL OIL OBTAINED BY MICROWAVE-ASSISTED HYDRODISTILATION METHOD}

\begin{abstract}
Characteristic properties of essential oil extracted from Pelargonium graveolens (rose-scented geranium) were examined and its usage as a natural additive in apple juice was investigated in this study. Microwave assisted hydrodistilation method has been used and essential oil was produced with a yield of $1.75 \%$. Gas chromatography mass spectrometry was used to identify volatile compounds. The main volatile compounds of geranium essential oil were citronellyl formate, isomenthone, linalool, citronellol and geraniol. The antioxidant activity of the essential oil was found to be $0.54 \mathrm{mM}$ trolox $/ \mathrm{mL}$ oil. The antibacterial effect of the essential oil was found to be higher on Staphylococcus aureus compared to Escherichia coli. It was determined that the microbial load of apple juice added with the
\end{abstract}

* Yazışmalardan sorumlu yazar/ Corresponding Author

117: yoncayuceer@comu.edu.tr

(0: (+90) 2862180018 / 20051

圆: (+90) 2862180541

Pelin Aydınlık; ORCID No: 0000-0003-0519-0993

Yonca Karagül Yüceer; ORCID No: 0000-0002-9028-2923 
essential oil decreased during storage. In addition, it was demonstrated by consumer test that apple juice with added essential oil was acceptable in terms of sensory properties.

Keywords: Pelargonium graveolens, rose-scented geranium, essential oil, antioxidant activity, antibacterial activity, sensory

\section{GİRİŞ}

Bitkilerin tohum, yaprak, çiçek, kök ve kabuklarından elde edilen, bitkiye özgü karakteristik bir kokuya sahip uçucu bileșiklere esansiyel yağlar denir. Esans, aromatik yağ, uçucu yağ, eterik yăg gibi birçok farklı şekilde adlandırılırlar. Suda çözünmedikleri için yă̆ olarak tanımlanırlar, fakat sabit yağlardan farklıdırlar. Organik çözücülerde çözülebilirler. Bileşimlerinin büyük bir çoğunluğu terpenlerden (özellikle monoterpenlerden) oluşur. Bileşim ve miktar değişimi üzerine bitkinin yetiştiği coğrafya, bitki cinsi ve bitkinin kısımlar1 etkilidir (Bayaz, 2014). Daha çok sıcak tropik bölgeler ile ılıman Akdeniz bölgesinde yetişmekte olan bitki türlerinden elde edilen yaklaşık 3000 esansiyel yağ çeşidi vardır. Ancak bunların 300 kadarı ticari olarak önem taşır (Kürekçi ve Sakin, 2017). Esansiyel yağların ticari olarak kullanım alanları gida sanayi, ilaç, kozmetik ve alternatif tıp olarak adlandirılan fitoterapi ve aromaterapidir (Hammer vd., 1999).

Itır, diğer adı gül kokulu sardunya olan Pelargonium graveolens, Geraniaceae familyasina ait Güney Afrika'ya özgü çok yıllık, yarı çalı bir bitkidir (Ravindra ve Kulkarni, 2015). Cezayir, Misır, Fas, Reunion Adaları, Fransa, Çin ve Hindistan'da uçucu yağının üretimi için ticari ölçekte itır yetiştiriciliği yapılmaktadır (Ravindra ve Kulkarni, 2015). Antimikrobiyal, antioksidan, immünostimülan, hipoglisemik ve antiinflamatuvar etkiler gibi özellikler sergiler (Rahman vd., 2020). Esansiyel yağ esas olarak yapraklarında bulunsa da yapraklarıly birlikte gövdeleri de damitılabilir. Bu esansiyel yağ kozmetik ürünlere özellikle parfümlere ve gıdalara (reçel, şurup, jöle, içecek, kek vb.) gül kokusu vermek amaciyla kullanılmaktadır (Ravindra ve Kulkarni, 2015). Gül benzeri kokusu sayesinde daha pahalı olan gül yağının yerine kullanılabildiği için bazı ülkelerde halk arasında "fakir adamın gül yağ1" olarak anılır (Wells ve Lis-Balchin, 2002). Itır esansiyel yağ1, \%60-70 oranında linalol, sitronelol, geraniol ve bunların esterleri ile birlikte önemli miktarda izomenton, menton, nerol, $\alpha$-terpineol, $\alpha$-pinen, myrcen, $\beta$-filandren, cis ve trans rose oksit içermektedir (Charlwood ve Charlwood, 1991).

Gidalarda oksidasyonu engellemek amaciyla yapay antioksidanlar kullanılmaktadır. Yapay antioksidan olarak kullanılan bütillenmiş hidroksi toluen (BHT) ve bütillenmiş hidroksi anisol (BHA) canlılarda karsinojenik etkiye sahip olduğundan esansiyel yağların, antioksidan madde olarak kullanımı gida sanayinde bir alternatif yöntem olmuştur (Bayaz, 2014). Esansiyel yağların antioksidatif etkilerinin, bileşimde yer alan fenolik hidroksil gruplarından kaynaklandığı öne sürülmektedir (Cuvelier vd., 1996). Itır esansiyel yağının antioksidan aktivitesi; esansiyel yağın kimyasal bileşimi, fenolik madde içeriği ve flavonoid içeriği ile doğru orantılldır (Cavar ve Maksimovic, 2012). Itır esansiyel yağının radikal indirgeyici özelliği bulunmaktadır ve esansiyel yağın konsantrasyonu arttıkça artmaktadır (Fayed, 2009).

Esansiyel yağlar yüksek antibakteriyel etkiye de sahip olduğundan gida sanayinde, kimyasal koruyuculara ve antibiyotiklere alternatif koruyucu ajan olarak kullanım alanı bulmaktadırlar. Etki mekanizmaları kısaca, lipofilik terpenlerin, mikroorganizmanın hücre duvarındaki lipitlerle etkileşime geçerek etki etmesi ve hücre duvarı bütünlügünün bozularak geçirgenliğin azalması şeklinde açıklanmaktadır (Erdoğan ve Everest, 2013).

Esansiyel yağ elde etmek için kullanılan metot doğrudan esansiyel yağın kalitesi ve verimi üzerinde etkilidir. Esansiyel yağlar, temel olarak distilasyon, ekstraksiyon ve presleme yöntemleriyle elde edilmektedir (Kaya ve Ergönül, 2015). Endüstriyel esansiyel yă̆ üretimi için damıtma yöntemi ilk olarak Misır, İran ve Hindistan'da kullanılmışır (Guenther ve Althausen, 1948). Gida sanayisinde yaygin olarak geleneksel distilasyon yöntemleri 
kullanılmaktadır. Özellikle su ile distilasyon (hidrodistilasyon) eskiden beri çok yaygın olarak tercih edilen bir yöntem olmuştur. Fakat uzun süren damıtma süresi maliyeti arttırmaktadır. Gelişen teknoloji ile mikrodalga destekli hidrodistilasyon yöntemi geleneksel yöntemde karşılaşılan sorunlara çözüm olmuştur. Kısa damıtma süresi, düşük enerji sarf etmesi, yüksek verim sağlaması ve çevre dostu olması mikrodalga destekli hidrodistilasyonun geleneksel yönteme göre en belirgin avantajlarıdır (Bayaz, 2014; Kaya ve Ergönül, 2015).

$\mathrm{Bu}$ çalışmada Pelargonium graveolens (1tır) bitkisinden mikrodalga destekli hidrodistilasyon yöntemiyle esansiyel yağ etmek ve bu esansiyel yağın antioksidan ve antimikrobiyel özelliklerini ortaya koymak hedeflenmiştir. Ayrıca elde edilen esansiyel yağın gida uygulaması sonucu üründeki mikrobiyel ve duyusal özelliklerin de belirlenmesi amaçlanmıştır.

\section{MATERYAL VE YÖNTEM \\ Materyal ve Örnek Hazırlama}

Itır bitkisi (Pelargonium graveolens), Damlica Çiftliğinden (Çatalca/İstanbul) taze olarak temin edilmiştir. Taze bitki örneği nem olmayan bir ortamda, oda sıcakllğında kurutulmuş ve kuru halde koli içerisinde muhafaza edilmiştir. Kuru bitki örneklerinin yaprakları öğütücü (GM 200 Model, Knife Mill GRINDOMIX, Retsch GmbH, Düsseldorf, Almanya) kullanilarak öğütülmüştür. Yapraklar 6000 rpm'de 10 saniye boyunca öğütme işlemine tabi tutulmuştur.

\section{Bitki Örneğinin Nem ve Kül Analizi}

Nem tayini, su ile karışmayan toluen kullanılarak Dean\&Stark aparatı yardımıyla volumetrik olarak (Dean ve Stark, 1920; Anonymous, 1987) belirlenmiştir. Kül tayini kül firınında (Protherm, Ankara, Türkiye) $550{ }^{\circ} \mathrm{C}$ 'de örneğin yakılması sonucu gravimetrik olarak hesaplanmıştır (Cemeroğlu, 2007). Sonuçlar \% olarak ifade edilmiştir.

\section{Itır Bitkisinden Fenolik Ekstrakt Hazırlanması \\ Öğütülmüş bitki örneğinden metanollü fenolik ekstraktların hazırlanmasinda Kırca ve Arslan,}

(2008)'in önerdiği metot kullanılmışır. $0.5 \mathrm{~g}$ tartılan bitki örneğine $10 \mathrm{~mL}$ metanol eklenerek 300 rpm'de oda sıcaklı̆̆ında çalkalamalı inkübatörde bir saat tutulmuştur. Ardından 5204 x g'de 10 dakika süreyle santrifüj edilmiştir. Santrifüj sonrası metanol fazlar1 ayrilarak, tüm prosedür 3 kere tekrar edilmiş ve ayrilan metanollerin son hacmi 50 mL'ye tamamlanmıştır. Filtrasyonu (Whatmann No:1) takiben tüm fenolik ekstraktlar $\quad-18 \quad{ }^{\circ} \mathrm{C}$ 'de muhafaza edilmiştir.

\section{Itır Esansiyel Yağının Eldesi ve Yağa} Uygulanan Analizler

Ögütülmüş kuru bitki örneğinden esansiyel yağın elde edilmesinde mikrodalga destekli hidrodistilasyon yöntemi seçilmiştir ve ekstraksiyon Mikrodalga Destekli Clevenger aparat1 (Milestone Ethos, İtalya) kullanarak gerçekleştirilmiştir. Öğütülmüş kuru bitki örneği $(120 \mathrm{~g})$, cihazin cam ekstraksiyon haznesine koyularak 1:10 (w/w) oraninda su ile 1 saat boyunca oda sıcaklı̆̆ında ve ağzı kapalı bir şekilde bekletilmiştir. Ardından cam ekstraksiyon haznesi ve Clevenger aparatlı geri soğutucu sistem cihaza yerleştirilmiştir. Ön denemelerle belirlenen mikrodalga gücünde $(750 \mathrm{~W}) 2$ saat distilasyon işlemi uygulanmıştır.

\section{Uçucu Bileşenlerin Belirlenmesi}

Itır esansiyel yağının uçucu bileşenlerinin tanımlanması ve miktarının belirlenmesi amacıyla Gaz Kromatografisi-Kütle Spektrometresi (GCMS) (Agilent Technologies, GC 6890, MS 6890N, Wilmington, DE, ABD) kullanılmıştır. Örnekte bulunan uçucu bileşenler katı faz mikroekstraksiyon (SPME) tekniği ile izole edilmiş olup ayırma işlemi DB5 kolon (Agilent Technologies, $60 \mathrm{~m}, 0.32 \mathrm{~mm}$ id x $0.25 \mu \mathrm{m}$ film kalınlığı) kullanılarak gerçekleştirilmiştir. 40 mL'lik SPME vialine $300 \mu \mathrm{L}$ saf su ile $5 \mu \mathrm{L}$ esansiyel yağ, metanolde seyreltilen ve konsantrasyonu $3.65 \mathrm{mg} / \mathrm{mL}$ olan iç standarttan ( $\alpha$-thujone) $10 \mu \mathrm{L}$ eklenmiş ve $40{ }^{\circ} \mathrm{C}$ 'de $5 \mathrm{dk}$ süreyle su banyosunda bekletilmiştir. Ardından su banyosundaki viale fiber batırlarak $40{ }^{\circ} \mathrm{C}$ 'de $5 \mathrm{dk}$ daha bekletilmiştir. Süre bitiminde fiber yüzeyine adsorbe olan uçucu bileşenler GC-MS'e enjekte edilerek analize başlanmıştır. 
GC şartları: Taşıyıcı gaz: Helyum, $1.5 \mathrm{~mL} / \mathrm{dk}$, enjeksiyon türü: Bölünmüş (split), Bölünme oranı (Split ratio): 25/1, dedektör: kütle spektrometresi, firın programı: Başlangıç sıcaklığı $40^{\circ} \mathrm{C}^{\prime} \mathrm{de} 3 \mathrm{dk}$, Ramp1: $3^{\circ} \mathrm{C} / \mathrm{dk}, 200{ }^{\circ} \mathrm{C}$ 'de $10 \mathrm{dk}$, Ramp2: $10^{\circ} \mathrm{C} / \mathrm{dk}, 240{ }^{\circ} \mathrm{C}$ 'de $5 \mathrm{dk}$, toplam süre $75 \mathrm{dk}$.

MS şartları: Kapiler arayüz sıcaklığı: $280{ }^{\circ} \mathrm{C}$, iyonizasyon enerjisi: 70 eV, kütle ağırlığı 35 ile 350 amu, tarama hiz1 4.45 scans/s.

Spektral Kütüphane: National Institude of Standards and Technology (NIST, 2008) ve Wiley Registry of Mass Spectral Data (Wiley, 2005).

\section{Antibakteriyel Aktivitenin Belirlenmesi}

Itır esansiyel yağının antibakteriyel aktivitesi agar disk difüzyon metodu ile test edilmiştir (Ghannadi vd., 2012). Antibakteriyel aktivitesinin belirlenmesinde Gram (+) bakteri olan Staphylococcus aureus ATCC 6538, Gram (-) olan Escherichia coli ATCC 25922' nin referans suşları kullanılmıştır. Brain Heart (Oxoid, İngiltere) sıv1 besiyerinde ön canlandirma yapildiktan sonra, Nutrient Broth (Oxoid) s1v1 besiyerine inoküle edilen bakteriler spektrofotometrede (Shimadzu, Kyoto, Japonya) 0.5-0.6 absorbans değerine kadar $37{ }^{\circ} \mathrm{C}$ 'de inkübe edilmiştir. Ardından Müller Hinton (Acumedia Lab/Veogen, İngiltere) agar besiyerine yayma plak yöntemiyle ekim yapılmıştır. Esansiyel yağdan $15 \mu \mathrm{L}$ steril, boş kağıt disklere $(6 \mathrm{~mm})$ (Antimicrobial Susceptibility Test Dics, Oxoid Limited, İngiltere) emdirilerek, ekim yapilan besiyerlerine yerleştirilmiş ve $37^{\circ} \mathrm{C}$ 'de 24 saat inkübasyona birakılmıştır. İnkübasyon sonunda inhibisyon zon çapları ölçülmüştür.

\section{Antioksidan Aktivitesinin Belirlenmesi}

Esansiyel yağın ve metanollü fenolik ekstraktların antioksidan aktivitelerinin belirlenmesinde Trolox Eşdeğer Antioksidan Kapasitesi (TEAC) metodu kullanılmıștır (Re ve diğerleri, 1999). Metot ABTS (2,2'-azinobis-(3-etilbenzotiazolin-6-sulfonik asit))'in oksidasyonuyla üretilen ABTS $^{\bullet}$ radikal çözeltisi üzerine, antioksidan içeren bir örneğin eklenmesi sonucu radikalin indirgenmesi temeline dayanmaktadır. Esansiyel yağın seyreltilmesinde \%80'lik metanol, metanollü fenolik ekstraktların seyreltilmesinde ise Phosphate Buffered Saline
(PBS, tuzlu fosfat tampon) kullanılmıştır. Sonuçlar standard troloks kurvesinin eğiminden hesaplanarak esansiyel yağ için "mM troloks $/ \mathrm{mL}$ yağ", fenolik ekstrakt için "mM troloks/g bitki” olarak verilmiştir.

\section{Toplam Fenolik Madde Miktarının Belirlenmesi}

Esansiyel yağın ve metanollü fenolik ekstrakların toplam fenolik madde içeriğinin belirlenmesinde Folin-Ciocalteu metodu kullanılmıştır (Kırca ve Arslan, 2008). Örneğin seyreltilmesinde \%80'lik metanol çözeltisi kullanılmıştır. Örnekten $100 \mu \mathrm{L}$ alınarak üzerine $900 \mu \mathrm{L}$ saf su eklenmiştir. $5 \mathrm{~mL}$ folin ayrrac1 ve $4 \mathrm{~mL}$ sodyum karbonat eklenmesiyle elde edilen mavi renkli karışım, karanlık bir ortamda 2 saat bekletilmiştir. Süre sonunda spektrofotometrede (Shimadzu UV Spectrophotometer, Kyoto, Japonya) 765 nm dalga boyunda köre karşı okuma yapılmıştır. Sonuçlar standard gallik asit kurvesinin denkleminden hesaplanarak esansiyel yağ için "mg GAE/L yağ”, fenolik ekstrakt için “mg GAE/kg bitki” olarak verilmiştir.

\section{Elma Suyu Uygulamas1}

Çalışmada elma suyunun taze tüketimi amaçlanmış olup endüstriyel prosedürler uygulanmadan, sadece esansiyel yağ katkısının raf ömrü ile tat ve aroma üzerine etkisi incelenmiştir. Elma suyunun hazırlanması amaciyla yerel bir manavdan alınan Pink Lady sert sulu elma çeşidi kullanılmıştır. Elmalar yıkandiktan sonra dilimlenmiş ve katı meyve sıkacağ1 (Fakir Hausgeräte K 1579, Almanya) kullanılarak sıkılmıştır. Elmaların posasını ayırmak için 2 kat tülbent bezi kullanılmıştır. Taze sıkılmış elma suları 100 mL'lik kapaklı şişelere koyulmuş ve farklı konsantrasyonlarda $(100 \mathrm{~mL}$ elma suyunda 2.5, 5 ve $7.5 \mu \mathrm{L})$ 1tır esansiyel yağ1 eklenmiştir. Ardindan homojenizatör (ESGE, M 133/2280, Ísviçre) ile 30 saniye boyunca karıştırılmıştır. Hazırlanan esansiyel yağ ilaveli elma suları toplam canlı ve maya-küf sayımı ile tüketici testinde kullanılmıştır.

\section{Toplam Canlı Aerobik Mezofilik Bakteri (TCAMB) ve Maya-Küf Sayımı}

Taze sıkılmış elma suları 100 mL'lik kapaklı şişelere koyulmuş ve farklı konsantrasyonlarda 
eklenen 1tır esansiyel yağ1 $(100 \mathrm{~mL}$ elma suyunda $2.5,5$ ve $7.5 \mu \mathrm{L}$ ) ile 15 gün boyunca buzdolab1 koşullarında $\left(4 \pm 2{ }^{\circ} \mathrm{C}\right)$ depolanmıstır. Haftalık periyotlarla (0.gün, 7.gün, 15.gün) aseptik koşullarda toplam canlı ve maya-küf sayımı gerçekleştirilmiştir. Esansiyel yağın elma suyu içerisinde homojen dağılması için 1:1 oranında Dimetil Sülfoksit (DMSO) içerisinde çözündürülmüş ve elma suyuna ilave edilmiştir. Böylece $100 \mathrm{~mL}$ elma suyunda 2.5, 5 ve $7.5 \mu \mathrm{L}$ konsantrasyonlarında esansiyel yağ ve $2.5,5$ ve 7.5 $\mu \mathrm{L}$ konsantrasyonlarında DMSO bulunmaktadir. Kontrol grubu elma sular1 belirtilen konsantrasyonlarda sadece DMSO içerecek şekilde hazırlanmıştır (Rosato vd., 2018). Seri dilüsyonlarda ilk dilüsyon $10 \mathrm{~mL}$ örnek ve $90 \mathrm{~mL}$ peptonlu su (\%0.1) ile takip eden dilüsyon $1 \mathrm{~mL}$ örnek ve $9 \mathrm{~mL}$ peptonlu su (\%0.1) olacak şekilde hazırlanmıştır. Hazırlanan dilüsyonlardan TCAMB için $1 \mathrm{~mL}$ alınarak Plate Count Agar (PCA; Merck KGaA, Darmstadt, Almanya) besiyerine dökme plak yöntemiyle, maya-küf için $100 \mu \mathrm{L}$ alınarak Dichloran Rose Bengal Chloramphenicol (DRBC; Merck, Darmstadt, Almanya) besiyerine yayma plak yöntemiyle ekimler gerçekleştirilmiştir. Petriler $30 \pm 2{ }^{\circ} \mathrm{C}$ 'de TCAMB için 2 gün, maya ve küf için 5 gün inkübasyona bırakılmıştır (Feglo ve Sakyi, 2012; Tournas vd., 2006).

\section{Duyusal Analizler}

Esansiyel yağlarda aroma profilini belirlemek amacıyla tanımlayıc1 duyusal analiz tekniği (Spektrum ${ }^{\mathrm{TM}}$ ) ve esansiyel yağın farklı konsantrasyonlarda eklendiği elma sularında ise tüketici testi kullanılmıştır (Meilgaard vd., 1999). Tanımlayıcı duyusal analiz için panelistlere test tekniği, aroma profilleri, referans aromalar vb. konularda 20 saat eğitim verilmiştir. Tanımlayıcı duyusal analizde, $1 \mu \mathrm{L}$ esansiyel yağ emdirilen kâğıt 30 mL'lik kapaklı cam kavanozlara koyulmuştur ve laboratuvar ortamında oda sıcaklı̆̆ında eğitimli panelistlerden tepe boşluğunun koklanması istenmiştir. 2 oturumda gerçekleşen panelde, panel lideri öncülüğünde karşl1kklı değerlendirme ve tartışma yaparak 10 panelist (25-52 yaş) tarafından tanımlayıcı terimler belirlenmiş ve 10 puanlık skala üzerinden değerlendirilmiştir. Tüketici testinde $100 \mathrm{~mL}$ elma suyuna ayr1 ayr1 $2.5, \quad 5 \quad$ ve $7.5 \quad \mu \mathrm{L}$ konsantrasyonlarında eklenen esansiyel yağ homojenizatör (ESGE, M 133/2280, İsviçre) ile karıştırıldıktan sonra, 30 mL'lik kapaklı plastik sos kaplarına yaklaşık $10 \mathrm{~mL}$ itır esansiyel yağ içeren elma suyu olacak şekilde paylaştırılmış tır. 50 kişiye uygulanan tüketici testinde üç basamaklı kodlar verilen farklı esansiyel yağ içeriğine sahip elma suyu örnekleri değerlendirerek genel beğeni durumlarına göre sıralamaları istenmiştir.

\section{İstatistiksel Analiz}

Analiz sonuçlarının değerlendirilmesinde tek yönlü varyans analizi tekniği (ANOVA) ile TUKEY çoklu karşılaştırma testi kullanılmıştır. Varyans analizi şartlarını yerine getirmeyen sonuçlar (homojenlik ve normal dağılım) için Games-Howell post-hoc testinden yararlanılmıştır. Toplam canlı aerobik mezofilik bakteri sayıs1, maya ve küf sayısı üzerine grup, konsantrasyon ve depolama gününün etkisini incelemek amaciyla tekrarlanan ölçümlü varyans analizinden yararlanılmıştır. Farklılı̆̆ın hangi gruptan ya da alt gruptan kaynaklandiğını belirlemek amacıyla TUKEY çoklu karşılaştırma testi kullanılmıştır. Toplam canlı aerobik mezofilik bakteri sayısı ile maya ve küf sayısı verilerine istatistiksel analize tabi tutulmadan önce logaritmik transformasyon uygulanmıştır. Tüketici testine ait sıralama sonuçları Friedman non-parametrik testi ile belirlenmiş ve istatistiksel olarak önemli fark bulunan ortalamalara LSD (Least Significant Difference) testi uygulanmıştır. Ortalamalar arasinda istatistiksel olarak anlamlı farklar olup olmadığ $P \leq 0.05$ önem derecesinde belirlenmiştir. İstatistiksel analizler Minitab 17, IBM SPSS Statistics 21 ve Statistica 12 paket programlarıly gerçekleştirilmiştir.

\section{SONUÇ VE TARTIŞMA}

\section{Itır Bitkisine ait Fiziksel Analizler ve} Esansiyel Yağ Verimi

Itır bitkisinin nem içeriği toluen yöntemiyle $\% 8$, kül miktarı da \%7.57 olarak belirlenmiştir. Türk Gida Kodeksi Baharat Tebliğine (Anonymous, 2013) göre yaprak/çiçek baharatın nem miktarının en çok \%7.5-10, kül miktarının ise en çok \%7-15 arasında olabileceği ifade edilmektedir. Analiz edilen 1tır bitkisinin kül ve nem miktarları tebliğe uygun bulunmuştur. 
Çizelge 1. Itır esansiyel yağında bulunan uçucu bileşenler

Table 1. Volatile components in rose-scended geranium essential oil

\begin{tabular}{|c|c|c|c|c|c|}
\hline RI & $\begin{array}{l}\text { Bileşen/ } \\
\text { Component }\end{array}$ & $\begin{array}{c}\text { İçerik/Content } \\
(\mathrm{mg} / \mathrm{mL})\end{array}$ & RI & $\begin{array}{l}\text { Bileşen/ } \\
\text { Component }\end{array}$ & $\begin{array}{l}\text { İçerik/Content } \\
(\mathrm{mg} / \mathrm{mL})\end{array}$ \\
\hline 761 & Toluen & $0.06 \pm 0.02$ & 1227 & Sitronelol & $56.90 \pm 23.40$ \\
\hline 780 & $\begin{array}{l}\text { 4-metil-2,3- } \\
\text { dihidrofuran }\end{array}$ & $0.12 \pm 0.06$ & 1238 & Neral (Z-Citral) & $5.47 \pm 1.99$ \\
\hline 799 & Hekzanal & $0.08 \pm 0.03$ & 1250 & Geraniol & $25.40 \pm 10.80$ \\
\hline 850 & 2-Hekzenal & $0.19 \pm 0.07$ & 1257 & Piperiton & $0.32 \pm 0.11$ \\
\hline 932 & $\alpha$-Pinen & $2.09 \pm 0.47$ & 1267 & Geranial (E-Citral) & $5.01 \pm 1.90$ \\
\hline 941 & $\begin{array}{l}\text { 3-metil-1,4- } \\
\text { heptadien }\end{array}$ & $0.05 \pm 0.01$ & 1274 & Sitronelil format & $84.10 \pm 30.50$ \\
\hline 955 & trans-2-Heptenal & $0.16 \pm 0.03$ & 1284 & Vitispiran & $0.32 \pm 0.10$ \\
\hline 961 & Benzaldehit & $0.14 \pm 0.04$ & 1297 & Geraniol format & $22.34 \pm 8.79$ \\
\hline 969 & Linalol 3,7-oksit & $0.75 \pm 0.15$ & 1347 & Sitronelil asetat & $0.87 \pm 0.38$ \\
\hline 982 & $\begin{array}{l}\text { 6-metil-5-hepten-2- } \\
\text { on }\end{array}$ & $0.59 \pm 0.15$ & 1350 & $\alpha$-Kubeben & $1.76 \pm 0.68$ \\
\hline 987 & $\beta$-Mirisen & $2.38 \pm 0.58$ & 1374 & $\alpha$-Ylangen & $0.39 \pm 0.16$ \\
\hline 1004 & Kozmen & $0.39 \pm 0.07$ & 1375 & Geranil asetat & $1.52 \pm 0.68$ \\
\hline 1006 & Felandren & $0.90 \pm 0.14$ & 1380 & $\alpha$-Kopaen & $5.07 \pm 1.95$ \\
\hline 1010 & 2,4-Heptadienal & $0.12 \pm 0.04$ & 1389 & $\beta$-Burbonen & $6.78 \pm 2.69$ \\
\hline 1017 & $\alpha$-Terpinen & $0.21 \pm 0.03$ & 1393 & $\beta$-Elemen & $1.67 \pm 0.72$ \\
\hline 1024 & p-Simen & $1.39 \pm 0.26$ & 1413 & $\alpha$-Gurjunen & $0.87 \pm 0.35$ \\
\hline 1029 & Limonen & $2.26 \pm 0.41$ & 1426 & trans-Karyofilen & $6.90 \pm 2.94$ \\
\hline 1031 & $\beta$-Felandren & $1.03 \pm 0.11$ & 1437 & Sitronelil propionat & $0.44 \pm 0.23$ \\
\hline 1034 & (E)- $\beta$-Osimen & $3.02 \pm 0.53$ & 1446 & 3,7-Guaiadien & $1.99 \pm 0.92$ \\
\hline 1044 & Sitren oksit & $0.20 \pm 0.04$ & 1455 & İzoleden & $2.61 \pm 1.18$ \\
\hline 1045 & (Z)- $\beta$-Osimen & $5.08 \pm 0.92$ & 1462 & $\alpha$-Karyofilen & $1.72 \pm 0.81$ \\
\hline 1058 & $\gamma$-Terpinen & $0.15 \pm 0.03$ & 1467 & Aromadendren & $3.84 \pm 1.86$ \\
\hline 1071 & $\begin{array}{l}\text { cis-furan Linalol } \\
\text { oksit }\end{array}$ & $1.11 \pm 0.39$ & 1484 & $\gamma$-Muurolen & $0.60 \pm 0.29$ \\
\hline 1085 & $\alpha$-Terpinolen & $1.43 \pm 0.27$ & 1487 & Germakren D & $3.32 \pm 1.57$ \\
\hline 1086 & (Z)-Linalol oksit & $0.39 \pm 0.15$ & 1496 & Leden & $7.33 \pm 3.63$ \\
\hline 1090 & o-izopropeniltoluen & $0.84 \pm 0.20$ & 1498 & epi-Bisikloseskifilandren & $0.59 \pm 0.31$ \\
\hline 1100 & Linalol & $65.80 \pm 19.10$ & 1522 & $\delta$-Kadinen & $3.27 \pm 1.74$ \\
\hline 1102 & $\begin{array}{l}\text { 6-metil-3,5- } \\
\text { heptadien-2-one }\end{array}$ & $1.67 \pm 0.60$ & 1524 & cis-Kalamenen & $0.28 \pm 0.15$ \\
\hline 1110 & cis-Rose oksit & $12.25 \pm 2.55$ & 1526 & trans-Kalamenen & $0.97 \pm 0.48$ \\
\hline 1126 & trans-Rose oksit & $4.25 \pm 0.99$ & 1537 & Epizonaren & $0.75 \pm 0.42$ \\
\hline 1158 & Menton & $3.12 \pm 0.85$ & 1541 & $\alpha$-Kadinen & $0.18 \pm 0.09$ \\
\hline 1161 & İzopülegol & $0.75 \pm 0.25$ & 1544 & Valencen & $0.12 \pm 0.07$ \\
\hline 1169 & İzomenton & $78.70 \pm 21.00$ & 1546 & $\alpha$-Kalakoren & $0.24 \pm 0.13$ \\
\hline 1190 & Neoizomentol & $0.75 \pm 0.25$ & 1553 & Geranil bütirat & $0.31 \pm 0.19$ \\
\hline 1193 & Metil salisilat & $0.09 \pm 0.001$ & 1584 & Feniletil tiglat & $0.34 \pm 0.20$ \\
\hline 1196 & $\alpha$-Terpineol & $4.19 \pm 1.55$ & 1694 & Geranil tiglat & $0.09 \pm 0.06$ \\
\hline
\end{tabular}

Sonuçlar ortalama \pm standart hata olarak verilmiştir. / Results are given as mean \pm standard error.

RI: Alıkonma indeksi/Retention Index 
Yağ eldesinde, kısa damıtma süresi, düşük enerji sarfiyatı, yüksek verim sağlaması ve çevre dostu olmas1 gibi avantajları ile mikrodalga destekli hidrodistilasyon yöntemi tercih sebebi olmaktadır (Bayaz, 2014; Kaya ve Ergönül, 2015). Bu yöntemle elde edilen 1 tır esansiyel yağında $\% 1.75$ verim sağlanmıştır. Mikrodalga destekli hidrodistilasyon tekniğinin, uygulama süresi 2-3 saat olan ve \%0.1-0.8 arasında verim sağlanan geleneksel hidrodistilasyon yöntemine kiyasla daha yüksek verim sağladığı belirtilmektedir (Ghannadi vd., 2012; Boukhatem vd., 2013; Boukhris vd., 2013). Ayrica Fardhyanti vd. (2019), Myristicae arillus esansiyel yağı elde etmek için farklı distilasyon teknikleri seçmişler ve bu amaçla mikrodalga destekli hidrodistilasyon tekniğinde uyguladıkları farklı mikrodalga güçleri (W) ile geleneksel hidrodistilasyon yöntemini kıyaslamışlardır. Mikrodalga destekli hidrodistilasyon yönteminin geleneksel hidrodistilasyon yönteminden daha verimli olduğunu, oksijenli monoterpenlerin ve diğer aromatik bileşenlerin daha fazla bulunduğunu, uygulanan güç arttıkça elde edilen esansiyel yă̆ veriminin arttığını belirtmişlerdir.

\section{Itır Esansiyel Yağının Uçucu Bileşenleri}

Pelargonium graveolens türü 1 tır bitkisinden elde edilen esansiyel yağda bulunan uçucu bileşenlerin tanımlanması ve miktarının belirlenmesi amacıyla GC/MS kullanılmıştır. Itır esansiyel yağında bulunan uçucu bileşenler Çizelge 1'de yer almaktadir.

Itır esansiyel yağının tatlı ve çiçeksi gül kokusunu ifade eden temel uçucu bileşenler sitronelol, sitronelil format ve geraniol olarak belirtilmiştir (Peterson vd., 2006; Bigos vd., 2012; Boukhatem vd., 2013; Singh vd.; 2013; Ali vd.; 2013). Çizelge 1 incelendiğinde, literatüre benzer biçimde 1tır esansiyel yağındaki temel uçucu bileşenleri sitronelol, sitronelil format, geraniol, linalol ve izomenton oluşturmaktadır. Bu çalışmada, yapılan bazı çalışmalara kiyasla sitronelol ve geraniol miktar1 geleneksel hidrodistilasyon metoduyla üretilen 1tır esansiyel yağlarına göre daha düşük bulunmuştur. Bununla birlikte izomenton ve linalol gibi Pelargonium graveolens türünde yüksek konsantrasyonlarda bulunabilen uçucu bileşenler tespit edilmiştir (Peterson vd., 2006; Boukhatem vd., 2013; Singh vd., 2013; Saxena vd., 2004). Sitronelol, 1tıra gül kokusu veren diğer bileşenlerden olan cis- ve trans- rose oksit sentezinde öncü bir bileşen olarak kabul edilmektedir (Saxena vd., 2004). Bu çalışmada da 1tır esansiyel yağında mevcut yüksek sitronelol konsantrasyonunun yüksek ve orta konsantrasyonda cis- ve trans- rose oksit oluşumunu etkilediği düşünülmektedir.

Bitkinin yetiştirildiği toprağa bağlı olarak değişmekte olup fosfor içeriği yüksek topraklarda veya fosforlu gübreleme yapilan topraklarda bitkideki 10-epi- $\gamma$-eudesmol uçucu bileşiğinin arttı̆̆1 belirtilmektedir (Pandey ve Patra, 2015). Bazı çalışmalarda yer alan ve düşük konsantrasyonlarda bulunan nerol ile 10-epi- $\gamma$ eudesmol bu çalışmada tespit edilememiştir (Bigos vd., 2012; Singh vd., 2013).

Uçucu bileşenlerin tespiti ve miktarı üretim metodunun yanı sıra bitkinin yetiştiği koşullara göre de değişkenlik göstermektedir. Ali vd. (2013) tarafindan yapılan çalışmada bitkinin yetiştiği kaynağa göre sitronelol miktar1 \%16'dan \%0.1'e, sitronelil format miktar1 \% 13.3 'ten $\% 1$ 'e, geraniol miktar1 \%16'dan \%0.1'e, izomenton miktar1 $\% 7.9$ 'dan tespit edilememesine, linalol miktarı $\% 10.4$ ten \%0.1'e kadar değiştiği belirtilmiştir.

Terpenler yapılarında 30000'den fazla bileşik içeren en büyük doğal bitki ürünleridir ve aynı zamanda yapısal olarak en geniş tür çeşitlerini içeren terpenlerin; birçok farklı monoterpen (C10), seskiterpen (C15), diterpen (C20), triterpen (C30), tetraterpenler (C40) ve politerpenler (>C40) karbon iskeleti olarak bilinmektedir (Ashour vd., 2018). Bu çalışmada belirlenen uçucu bileşenlerde başlica monoterpenlere (Degenhardt vd., 2009$) ; \quad \beta$-mirisen, $\alpha$-pinen, $\beta$-filandren, terpinolen, limonen, $\beta$-osimen, linalol, $\gamma$-terpinen, $\alpha$-terpineol, geraniol örnek olarak verilebilir. Seskiterpenlere (Degenhardt vd., 2009) ise karyofilen, valencen, $\delta$-kadinen, germakren $\mathrm{D}, \beta$ elemen, $\alpha$-kubeben ve $\delta$-kadinen örnek verilmektedir. 


\section{Itır Esansiyel Yağının Antioksidan Aktivite ve Toplam Fenolik Madde Miktarı}

Itır esansiyel yağına ve metanollü fenolik ekstraktlarına ait antioksidan aktivite ve toplam fenolik madde (TFM) miktarları Çizelge 2'de verilmiştir. Çizelge 2'ye göre 1tır bitkisinden hazırlanan metanollü fenolik ekstraktı 1tır esansiyel yağından daha fazla fenolik madde içermekte olup daha yüksek antioksidan aktivite göstermektedir. Metanolün, toplam fenolik madde ekstraksiyonunda iyi bir çözücü olduğu düşünülmektedir. Benzer şekilde Boukhris vd., (2013) tarafindan metanollü ekstraktlarda antioksidan aktivite ve TFM miktarının yüksek bulunması metanolün fenolik madde ekstraksiyonunda iyi bir çözücü olduğunu göstermektedir. Bununla birlikte Çizelge 2'ye göre antioksidan aktivite artışının toplam fenolik madde miktarının artmasıyla doğrudan ilişkili olduğu görülmektedir. Benzer şekilde toplam fenolik madde miktarı ile radikal süpürme yeteneğinin doğru orantılı olduğu belirtilmektedir (Cavar ve Maksimovic, 2012; Boukhris vd., 2013). Bitkinin bileşimi ve yetiştirilme kaynağına göre antioksidan aktivitesi ve toplam fenolik madde miktarı değişebilir (Dzamic vd., 2014; Fayed, 2009). BHT sentetik antioksidan maddesi ile kıyaslandığında, 1tır esansiyel yağının, ABTS radikalini indirgeme etkisinin DPPH radikalini indirgeme etkisine göre daha fazla olduğu belirtilmiştir (Boukhris vd., 2013). Bunun aksine, Dzamic vd., (2014)'e göre 1tır esansiyel yağının DPPH radikalini indirgeme kapasitesi, sentetik antioksidan BHT'den daha yüksek değildir.

Çizelge 2. Itır esansiyel yağı ve metanollü fenolik ekstraktlarına ait antioksidan aktivite ve toplam fenolik madde (TFM) miktarı

Table 2. Antioxidant activity and total phenolic substance (TPS) amount of rose-scented geranium essential oil and methanolic phenolic extracts

\begin{tabular}{lcc}
\hline Örnek/Sample & $\begin{array}{c}\text { Antioksidan aktivite TEAC Değeri } \\
\text { Antioxidant activity TEAC V alue }\end{array}$ & $\begin{array}{c}\text { TFM Miktar1 } \\
\text { TPS Amount }\end{array}$ \\
\hline Itır EY/ Rose-scented geranium EO & $0.54 \pm 0.004^{1}$ & $58.06 \pm 0.12^{3}$ \\
Itır FE/ Rose-scented geranium PE & $76.39 \pm 0.69^{2}$ & $1478.13 \pm 9.38^{4}$ \\
\hline
\end{tabular}

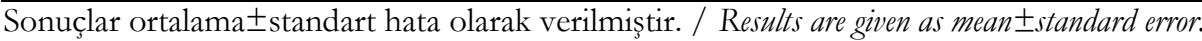

1: $\mathrm{mM}$ troloks/mL yağ 2: $\mathrm{mM}$ troloks/g bitki 3: $\mathrm{mg}$ GAE/L yağ 4: $\mathrm{mg}$ GAE/kg bitki

1: $\mathrm{mM}$ trolox/mL oil 2: $\mathrm{mM}$ trolox/g plant 3: $\mathrm{mg}$ GAE/ $\mathrm{kg}$ plant 4: $\mathrm{mg}$ GAE/kg plant

EY: Esansiyel yăg; FE: Fenolik ekstrakt; GAE: Gallik asit eşdeğeri/EO: Essential oil; PE: Phenolic extract; GAE: Gallic acid equivalent

Itır esansiyel yağında bulunan sitronelol ve geraniol antioksidan aktiviteye sahip bileşenlerdir ve antikanser aktivitenin de bu bileşenlerle pozitif korelasyon gösterdiği belirtilmektedir (Fayed, 2009). Sitronelol antikanser ve antiinflamatuar özelliklere sahip, yağda çözünen bir bileşendir. Geraniolün pankreas tümör hücrelerinin büyümesini inhibe ettiği (\%60-90) bulunmuştur (Fayed, 2009). Tüm bu sonuçlar 1şı̆̆ında 1tır bitkisinden elde edilen esansiyel yağın veya fenolik ekstrakt fraksiyonlarının doğal antioksidan madde olarak kullanılabileceği düşünülmektedir.

\section{Itır Esansiyel Yağının Antibakteriyel Aktivitesi}

Gram (+) bakteri ve Gram (-) bakteri suşları üzerinde 1 tır esansiyel yağının inhibisyon etkisinin agar disk difüzyon metoduyla incelendiği bu çalışmada, 1tır esansiyel yağının Escherichia coli üzerinde oluşturduğu inhibisyon çap1 $8.44 \mathrm{~mm}$, Staphylococcus aureus üzerinde oluşturduğu inhibisyon çap1 $14.72 \mathrm{~mm}$ olarak bulunmuştur. Bu araştırmaya göre 1tır esansiyel yağının Gram (+) bakteri olan Staphylococcus aureus suşuna, Gram (-) olan Escherichia coli suşundan daha fazla etki ettiği görülmüştür. Benzer şekildeki araştırmalarda 1tır (P. graveolens) esansiyel yağının $S$. aureus üzerine inhibisyon etkisinin $E$. coliye klyasla çok daha belirgin olduğu rapor edilmiştir (Dorman ve Deans, 2000; Jirovetz vd., 2006; Rosato vd., 2007). Bakterilerin Gram (+) veya (-) olmasinin esansiyel yağların antibakteriyel etkinliğinde önemli bir farklılık oluşturmadığını ileri süren görüşe karşılık, esansiyel yağların antibakteriyel aktivitesine Gram (+) bakterilerin Gram (-) bakterilerden daha dirençli olduğunu belirten 
görüşler de bulunmaktadır (Dorman ve Deans, 2000). Bir başka görüşe göre de 1tır esansiyel yağ1, Gram (+) bakterilere Gram (-) bakterilerden daha etkilidir (Ghannadi vd., 2012; Hsouna ve Hamdi, 2012; Boukhatem vd., 2013). Ayrıca bitki türüne göre değişen esansiyel yağlar arasında ve/veya farklı bitki türlerinde Gram (+) ve Gram (-) bakteriler üzerinde eşit antibakteriyel etki görülebileceği belirtilmiştir (Dorman ve Deans, 2000).

Temel aroma bileşenleri citronellol, geraniol ve bunların bazı türevlerinin, 1tır esansiyel yağının antibakteriyel aktivitesi ve maya, küf üzerinde kritik etkiye sahip olduğu bilinmektedir. Orta veya yüksek konsantrasyonda bulunan temel uçucu bileşenler ile düşük konsantrasyonda bulunan antibakteriyel etkiye sahip bileşenlerin kombinasyonu sonucu bu inhibisyon etki oluşabilmektedir (Jirovetz vd., 2006).

\section{Elma Suyu Uygulamasinda Toplam Canlı Aerobik Mezofilik Bakteri (TCAMB) ve Maya-Küf Sayımı}

Depolama boyunca kontrol grubunda ve farklı konsantrasyonlarda 1 tır esansiyel yağ grupta toplam canl1 aerobik mezofilik bakterilerine ait sayım sonuçları Çizelge 3'te verilmiştir.

Çizelge 3. Itır esansiyel yağı eklenen elma suyunda depolama boyunca toplam canlı aerobik mezofilik bakteri sayıs $(\log (\mathrm{kob} / \mathrm{mL}))$

Table 3. Total viable aerobic mesophilic bacteria count in apple juice with rose-scented geranium essential oil added during storage. $(\log (c f u / m L))$

\begin{tabular}{|c|c|c|c|c|}
\hline \multirow{2}{*}{$\begin{array}{l}\text { Grup } \\
\text { Group }\end{array}$} & \multirow{2}{*}{$\begin{array}{l}\text { Konsantrasyon/ Concentration } \\
(\mu \mathrm{L} / 100 \mathrm{~mL} \text { elma suyu/apple juice) }\end{array}$} & \multicolumn{3}{|c|}{ Depolama/storage } \\
\hline & & 0.gün/day & 7.gün/day & 15.gün/day \\
\hline \multirow{3}{*}{$\begin{array}{l}\text { Kontrol } \\
\text { (DMSO'lu) } \\
\text { Control }\end{array}$} & 2.5 & $2.97 \pm 0.01 \mathrm{AcI}$ & $3.28 \pm 0.01 \mathrm{AbI}$ & $3.68 \pm 0.01^{\mathrm{AaI}}$ \\
\hline & 5 & $2.95 \pm 0.04 \mathrm{AcI}$ & $3.31 \pm 0.01 \mathrm{AbI}$ & $3.75 \pm 0.02^{\mathrm{AaI}}$ \\
\hline & 7.5 & $2.96 \pm 0.02^{\mathrm{AcI}}$ & $3.30 \pm 0.02^{\mathrm{AbI}}$ & $3.73 \pm 0.02^{\mathrm{AaI}}$ \\
\hline $\begin{array}{l}\text { Itır esansiyel } \\
\text { yağ1 }\end{array}$ & $2.5+2.5$ & $2.94 \pm 0.02^{\mathrm{AcI}}$ & $3.17 \pm 0.01^{\mathrm{AbI}}$ & $3.71 \pm 0.01 \mathrm{AaI}$ \\
\hline $\begin{array}{l}(\mathrm{EY}+\mathrm{DMSO}) \\
\text { rose-scented } \\
\text { geranium }\end{array}$ & $5+5$ & $2.82 \pm 0.01 \mathrm{AcI}$ & $3.01 \pm 0.03 \mathrm{AbII}$ & $3.55 \pm 0.01$ AaII \\
\hline essential oil & $7.5+7.5$ & $2.68 \pm 0.03 \mathrm{BbII}$ & $2.71 \pm 0.04 \mathrm{BbII}$ & $2.93 \pm 0.08^{\mathrm{BaII}}$ \\
\hline
\end{tabular}

Sonuçlar ortalama \pm standart hata olarak verilmiştir. / Results are given as mean standard error.

A-BAynı grup ve aynı depolama gününde farklı büyük harflerle gösterilen konsantrasyon ortalamaları arasındaki farklar önemlidir $(P \leq 0.05)$.

${ }^{A-B}$ The differences between the concentration averages shown in different uppercase letters on the same group and the same storage day are significant $(P \leq 0.05)$.

a-c Aynı grup ve aynı konsantrasyonda farklı küçük harflerle gösterilen depolama günü ortalamaları arasındaki farklar önemlidir $(P \leq 0.05)$.

${ }^{a-c}$ The differences between the storage day averages of the same group and the same concentration, shown in different lowercase letters, are significant $(P \leq 0.05)$.

I- IIAynı depolama günü ve aynı konsantrasyonda farklı Romen rakamlarıyla gösterilen grup ortalamaları arasındaki farklar önemlidir $(P \leq 0.05)$.

${ }^{I-I I}$ The differences between the group averages indicated by different Romen numerals at the same storage day and at the same concentration are significant $(P \leq 0.05)$.

kob: koloni oluşturan birim

cfu: colony forming unit 
Toplam canlı gelişimi ve inhibisyonu üzerine grup, konsantrasyon ve bağımlı değişken olan depolama günü faktörlerinin üçlü interaksiyonu önemli bulunmuştur. Kontrol grubu incelendiğinde aynı depolama gününde DMSO konsantrasyonunun bir etkisi görülmemiştir. $\mathrm{Bu}$ nedenle 1tır esansiyel yağının çözündürülmesinde kullanilan DMSO'nun inhibisyon üzerinde etkisinin olmadığ1 görülmüştür $(P \quad \leq 0.05)$. Randhawa (2006)'ya göre DMSO'nun hücre zarında bulunan porlara etki ederek hücre bütünlügünün bozulmasına sebep olduğu ve böylece inhibitör etkisinin bulunduğu belirtilmektedir. Fakat bu inhibitör etkinin kullanılan doz ile ilişskili olduğu, inhibitör etkinin $\% 0.25$ ten başladığı ve konsantrasyon arttıkça arttığ1 belirtilmektedir. Çalışmamızda da düşük konsantrasyonlarda kullanilan DMSO'nun inhibitör etkisinin gözlenmediği saptanmıştır.

Itır esansiyel yağı eklenen grup için konsantrasyon farkları incelendiğinde aynı gün için en yüksek etki $7.5 \mu \mathrm{L}$ konsantrasyonunda görülürken, $2.5 \mu \mathrm{L}$ ve $5 \mu \mathrm{L}$ konsantrasyonları arasında önemli bir fark bulunmamıştır $(P \leq 0.05)$.

Kontrol grubunda ayn1 konsantrasyonda depolama günü uzadıkça bakteri sayısı artarken, benzer biçimde, $2.5 \mu \mathrm{L}$ ve $5 \mu \mathrm{L}$ konsantrasyonlarında 1tır esansiyel yağ1 eklenen grupta depolama günü arttıkça bakteri sayıs1 artmıştır. $7.5 \mu \mathrm{L}$ konsantrasyonunda 0 . gün ve 7 . gün arasında depolama günü artşsının önemli bir etkisi görülmezken, 15. günde depolama günü etkisi önemli bulunmuştur $(P \leq 0.05)$.

Itır esansiyel yağı içeren grup ile kontrol grubu karşılaştırıldığında 0 . günde $2.5 \mu \mathrm{L}$ ve $5 \mu \mathrm{L}$ esansiyel yağ konsantrasyonlarının önemli bir inhibisyon etkisi görülmezken $7.5 \mu \mathrm{L}$ esansiyel yă konsantrasyonu önemli bir inhibisyon etki göstermiştir. Fakat depolama ilerledikçe 7 . gün ve 15. günde $2.5 \mu \mathrm{L}$ esansiyel yağ konsantrasyonu önemli bir etki göstermezken, $5 \mu \mathrm{L}$ ile $7.5 \mu \mathrm{L}$ esansiyel yağ konsantrasyonları önemli bir etki göstermiştir ve aralarındaki fark önemli bulunmuştur $(P \leq 0.05)$.

Elma suyu örneklerinin maya ve küf sayımı sonuçları Çizelge 4'te yer almaktadır. Maya ve küf sayıs1 üzerine depolama günü ve grup faktörlerinin ayrı ayrı etkisi önemli olmuştur. Toplam canlı sayımında olduğu gibi maya ve küf inhibisyonu üzerine DMSO'nun kullanılan konsantrasyonları etki etmemiştir.

Çizelge 4. Itır esansiyel yağı eklenen elma suyunda depolama boyunca maya ve küf sayısı $(\log (\mathrm{kob} / \mathrm{mL}))$

Table 4. Yeast and mold counts in apple juice with rose-scented geranium essential oil added during storage $(\log (\mathrm{cfu} / \mathrm{mL}))$

\begin{tabular}{lccccc}
\hline Grup & $\begin{array}{c}\text { Konsantrasyon/ } \\
\text { Group }\end{array}$ & \multicolumn{3}{c}{ Depolama/storage } & Ortalama/ \\
\cline { 3 - 5 } & elma suyu/apple juice) & 0. gün/day & 7. gün/day & 15. gün/day & Mean \\
\hline Kontrol & 2.5 & $3.39 \pm 0.02$ & $3.53 \pm 0.03$ & $4.18 \pm 0.13$ & \\
(DMSO'lu) & 5 & $3.45 \pm 0.02$ & $3.49 \pm 0.04$ & $4.21 \pm 0.02$ & $3.71 \pm 0.09^{\mathrm{A}}$ \\
Control & 7.5 & $3.41 \pm 0.04$ & $3.45 \pm 0.05$ & $4.29 \pm 0.01$ & \\
\hline $\begin{array}{l}\text { Ittr esansiyel } \\
\text { yağ1 }\end{array}$ & $2.5+2.5$ & $3.20 \pm 0.03$ & $3.22 \pm 0.10$ & $4.09 \pm 0.09$ & \\
$\begin{array}{l}\text { (EY+DMSO) } \\
\text { Rose-scented }\end{array}$ & $5+5$ & $3.16 \pm 0.02$ & $3.13 \pm 0.13$ & $4.01 \pm 0.02$ & \\
$\begin{array}{l}\text { geranium essential } \\
\text { oil }\end{array}$ & $7.5+7.5$ & $3.18 \pm 0.07$ & $3.06 \pm 0.02$ & $3.79 \pm 0.18$ & $3.43 \pm 0.10^{\mathrm{B}}$ \\
& & & & & \\
\hline
\end{tabular}

Sonuçlar ortalama \pm standart hata olarak verilmiştir. / Results are given as mean \pm standard error.

${ }^{a-b}$ Farklı küçük harflerle gösterilen ortalamalar arasındaki farklar önemlidir $(P \leq 0.05)$.

${ }^{a-b}$ The differences between the averages shown in different lowercase letters are significant $(P \leq 0.05)$.

${ }^{\mathrm{A}-\mathrm{B} F a r k l ı ~ b u ̈ y u ̈ k ~ h a r f l e r l e ~ g o ̈ s t e r i l e n ~ o r t a l a m a l a r ~ a r a s i n d a k i ~ f a r k l a r ~ o ̈ n e m l i d i r ~}(P \leq 0.05)$.

${ }^{A-B}$ The differences between the averages shown in different capital letters are significant $(P \leq 0.05)$.

kob: koloni oluşturan birim

cfu: colony forming unit 
Çizelge 4'e göre kontrol grubu ile karşılaştırıldığında ıtır esansiyel yağının maya ve küf üzerine konsantrasyondan bağımsız olarak önemli bir etkisi olmuştur $(P \leq 0.05)$. 0. günden 7 . güne depolamanın maya ve küf gelişimi üzerine önemli bir etkisi görülmezken, 15.günde depolamanın önemli bir etki gösterdiği görülmektedir $(P \leq 0.05)$. Gram $(+)$ ve Gram $(-)$ bakterilerde olduğu gibi mayaların inhibisyonu üzerinde de uçucu bileşenlerin miktar ve kombinasyonu önem taşımaktadır. Örneğin sitronelol, sitronelal, sitronelil izobütirat ve neril asetat içeriği yüksek bir esansiyel yağın maya üzerindeki etkisi düşük bulunmuştur (Jirovetz vd., 2006). Bu nedenle mayalar üzerindeki inhibisyon etkisinin bakterilere göre daha az olması, 1tır esansiyel yağ1 içeriğinde belirtilen bileşenlerin bulunma yoğunluğuna ve kombinasyonuna bağlanabilir.

\section{Duyusal Analizler}

Itır esansiyel yağına ait ve duyusal değerlendirme yöntemiyle belirlenen karakteristik tanımlayıcı aroma terimleri Şekil 1'de verilmiştir.

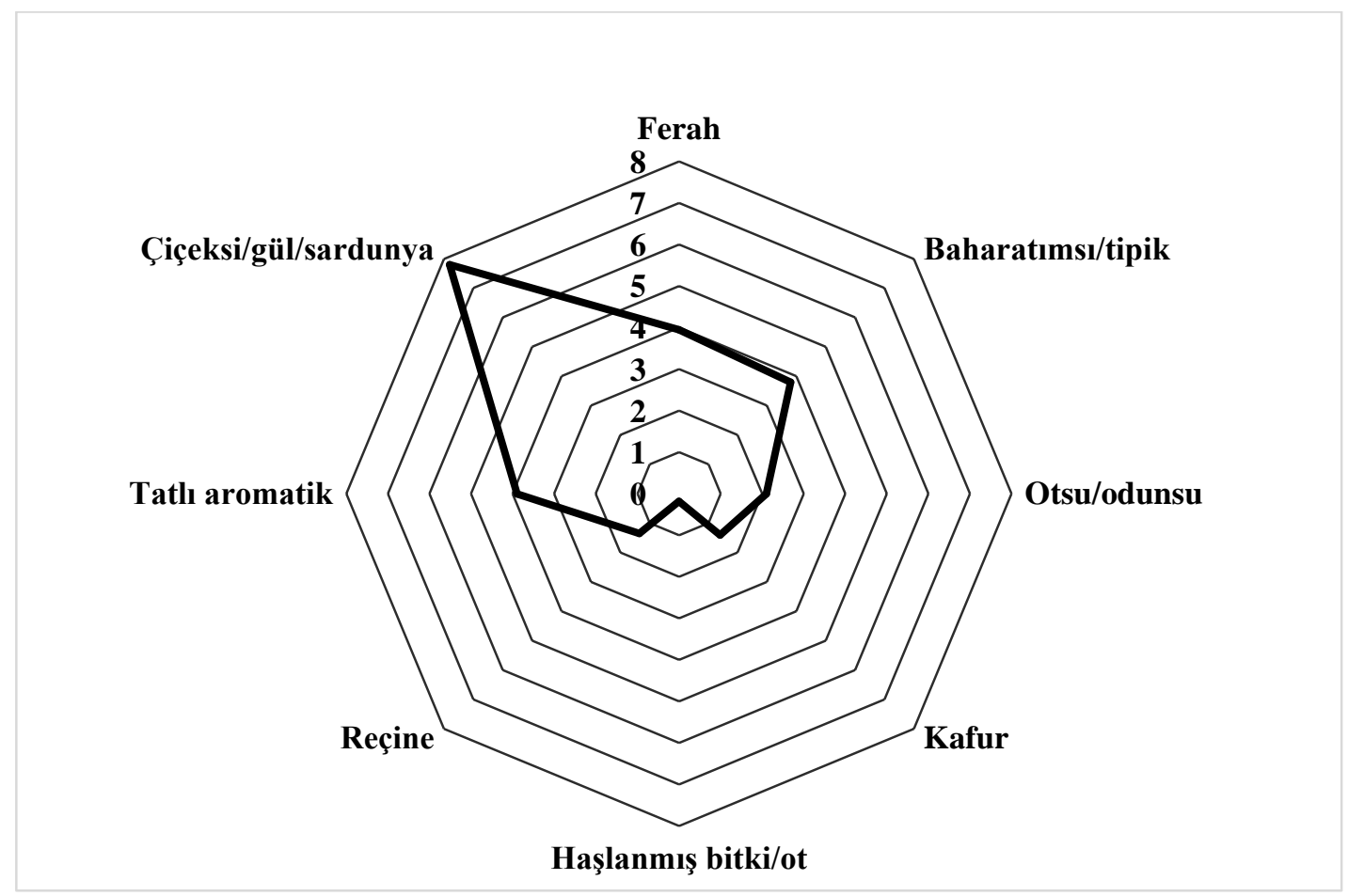

Şekil 1. Itır esansiyel yağına ait tanımlayıcı özellikler

Figure 1. Descriptive characteristics of rose-scented geranium essential oil

Şekil 1'e göre çiçeksi/gül/sardunya özellĭgi 1tır esansiyel yağı için en belirgin tanımlayıcı özellik olmuştur. Gül benzeri kokuyu sağlayan sitronelol ve geraniol uçucu bileşenleridir (Lapczynski vd., 2008; Chen ve Viljoen, 2010). Rose oksit bileşeni çiçeksi koku sağlarken otsu ve meyvemsi kokuyu da desteklemektedir (Yamamato vd., 2002). Çiçeksi kokuyu sağlayan diğer önemli uçucu bileşen linalol bileşenidir (Buccellato, 1982; Högnadottir ve Rouseff, 2003). Geraniol format, germakren $\mathrm{D}$, filandren, $\mathrm{p}$-simen, $\alpha$-pinen gibi daha düşük miktarlarda bulunan bileşenler ise tatl1, meyvemsi koku sağlamaktadır (Högnadottir ve Rouseff, 2003; Gomes vd., 2007). Taze, ferah koku yüksek konsantrasyonda bulunan izomenton ve takiben menton, geranial gibi uçucu bileşenlerden kaynaklanmaktadır (Gomes vd., 2007). Odunsu kokuya sahip muurolen, kubeben, elemen gibi düşük konsantrasyonlarda bulunan bileşenler esansiyel yağa odunsu ve reçinemsi kokuyu da vermektedir (Buccellato, 1982). Pelargonium esansiyel yağlarının karakterinde 
bulunan fakat istenmeyen haşlanmış bitki kokusuna düşük miktarda da olsa rastlanmıştır (Gomes vd., 2007). En belirgin tanımlayıc1 olan çiçeksi ve gül benzeri koku geraniol ve sitronelol uçucu bileşenlerinden kaynaklanırken; tatlı aromatik ve meyvemsi kokunun bu bileşenlerin formatlar1, asetatlar1 ve tiglatlar1 tarafindan sağlandığı belirtilmektedir (Gomes vd., 2007).

Farklı konsantrasyonlarda 1tır esansiyel yağ1 eklenen elma suyuna tüketici testi uygulanmış olup, sonuçlar Çizelge 5'te sunulmuştur.
Değerlendirmeye katılan panelistler $100 \mathrm{~mL}$ elma suyunda $2.5 \mu \mathrm{L}$ ve $5 \mu \mathrm{L}$ 1tır esansiyel yağı içeren konsantrasyonları daha çok beğenmiştir ve bu iki konsantrasyon arasında beğeni açısından önemli bir fark bulunmamıştır. Bunun yanı sıra $100 \mathrm{~mL}$ elma suyunda $7.5 \mu \mathrm{L}$ 1tır esansiyel yağı bulunan konsantrasyon daha az beğenilmiştir $(P \leq 0.05)$. Raf ömrü çalışması ve tüketici beğenisi göz önünde bulundurulduğunda 1 tır esansiyel yağ1 eklenmiş elma suyunun piyasada yeni bir ürün olarak değerlendirilebileceği düşünülmektedir.

Çizelge 5. Elma suyuna eklenen farklı konsantrasyonlardaki ıtır esansiyel yağına ait sıralama sonuçları Table 5. Ranking results of rose-scented geranium essential oil in different concentrations added to apple juice

\begin{tabular}{|c|c|c|c|}
\hline & \multicolumn{3}{|c|}{ Konsantrasyon/ Concentration ( $\mu \mathrm{L} / 100 \mathrm{~mL}$ elma suyu/apple juice) } \\
\hline & 2.5 & 5 & 7.5 \\
\hline $\begin{array}{l}\text { Siralama/ } \\
\text { Ranking }\end{array}$ & $1.50^{\mathrm{b}}$ & $1.84^{\mathrm{b}}$ & $2.66^{\mathrm{a}}$ \\
\hline
\end{tabular}

\section{SONUÇ}

Çalısmada Pelargonium graveolens cinsi olan gül kokulu sardunya diğer adiyla 1tır bitkisinden mikrodalga destekli hidrodistilasyon yöntemi ile elde edilen esansiyel yağın karakteristik bazı özellikleri incelenmiştir. Itur esansiyel yağının antioksidan aktivitesi olduğu belirlenmiştir ve doğal antioksidan madde olarak değerlendirilebileceği düşünülmektedir. Antibakteriyel aktivitesi incelendiğinde ise, çalışılan suşlar üzerindeki inhibisyon etkisinin Escherichia coliye kiyasla Staphylococcus aureus üzerinde çok daha belirgin olduğu saptanmıştır.

Tüketici tercihi ve 1tır esansiyel yağının depolama üzerine etkisi göz önüne alındığında, aerobik mezofil bakterilerin inhibisyonu üzerine en etkili konsantrasyon $100 \mathrm{~mL}$ elma suyunda $7.5 \mu \mathrm{L}$ konsantrasyonu iken, tüketici bakımından bu katkı oranının en düşük beğeni skoruna sahip olduğu görülmektedir. En beğenilen doz olan 100 $\mathrm{mL}$ elma suyunda $2.5 \mu \mathrm{L}$ konsantrasyonun ise aerobik mezofil bakterilerin inhibisyonu üzerine önemli bir etkisi bulunmamıştır. Maya ve küf inhibisyonu üzerine de konsantrasyon fark1 önemli bulunmadığından $100 \mathrm{~mL}$ elma suyunda 5 $\mu \mathrm{L}$ konsantrasyonunda esansiyel yağ kullanımının hem raf ömründe hem de tüketici beğenisinde tercih edilebilir konsantrasyon olduğu düşünülmektedir.

\section{TEŞEKKÜR}

Bu çalışma Çanakkale Onsekiz Mart Üniversitesi Bilimsel Araştırma Projeleri Koordinasyon Birimi tarafindan FYL-2020-3266 numaralı proje ile desteklenmiştir.

\section{ÇIKAR ÇATIŞMASI}

Yazarlar bu araştırma makalesinin herhangi bir kişi ve/veya kurum ile çıkar çatışması olmadığını beyan etmektedir.

\section{YAZAR KATKILARI}

Pelin Aydınlık araştırma konusunun tasarlanması, analizlerin gerçekleştirilmesi ve takibi, sonuçların değerlendirilmesi, istatistiksel analizler ve makale taslağının yazımını gerçekleştirmiştir. Yonca Yüceer araştırmanın süreç yönetimini, analizlerin metodolojisini, makale taslağının incelenmesini/düzeltilmesini ve bu projenin yürütücülügünü yapmıştır. 


\section{KAYNAKLAR}

Ali, A., Murphy, C. C., Demirci, B., Wedge, D. E., Sampson, B. J., Khan, I. A., Tabanca, N. (2013). Insecticidal and biting deterrent activity of rosescented geranium (Pelargonium spp.) essential oils and individual compounds against Stephanitis pyrioides and Aedes aegypti. Pest Manag Sci, 69(12), 1385-1392. doi: 10.1002/ps.3518

Anonymous, (1987). Baharat-Rutubet Miktar1 Tayini. Türk Standartları Enstitüsü 2134, Ankara.

Anonymous, (2013). Türk G1da Kodeksi Baharat Tebliği. 16.02.2009 tarih ve 28614 sayll Resmi Gazete, Ankara.

Ashour, M., Wink, M., Gershenzon, J. (2018). Biochemistry of terpenoids: monoterpenes, sesquiterpenes and diterpenes. Annu Plant Rev Online, 258-303. doi: 10.1002/9781119312994.apr0427

Bayaz, M. (2014). Esansiyel yağlar: antimikrobiyal, antioksidan ve antimutajenik aktiviteleri. Akademik Gıda, 12(3), 45-53.

Bigos, M., Wasiela, M., Kalemba, D., Sienkiewicz, M. (2012). Antimicrobial activity of geranium oil against clinical strains of Staphylococcus aureus. Molecules, 17(9), 10276-10291. doi: 10.3390/molecules170910276

Boukhatem, M. N., Kameli, A., Saidi, F. (2013). Essential oil of Algerian rose-scented geranium (Pelargonium graveolens): Chemical composition and antimicrobial activity against food spoilage pathogens. Food Control, 34(1), 208-213. doi: 10.1016/j.foodcont.2013.03.045

Boukhris, M., Simmonds, M. S., Sayadi, S., Bouaziz, M. (2013). Chemical composition and biological activities of polar extracts and essential oil of rose-scented geranium, Pelargonium graveolens. Phytother Res, 27(8), 1206-1213. doi: 10.1002/ptr.4853

Buccellato, F. (1982). Ylang survey. Perfum. Flavor, 7(4), 9-13.

Cavar, S., Maksimović, M. (2012). Antioxidant activity of essential oil and aqueous extract of Pelargonium graveolens L'Her. Food Control, 23(1), 263-267. doi: 10.1016/j.foodcont.2011.07.031
Cemeroğlu, B., (2007). Gıda Analiz̨leri (4. baski). Bizim Grup Basimevi, Ankara. 3-24.

Charlwood, B. V., Charlwood, K. A. (1991). Pelargonium spp. (Geranium): in vitro culture and the production of aromatic compounds. In Medicinal and Aromatic Plants III (pp. 339-352). Springer, Berlin, Heidelberg. doi: 10.1007/978-3642-84071-5_20

Chen, W., Viljoen, A. M. (2010). Geraniol-a review of a commercially important fragrance material. S Afr J Bot, 76(4), 643-651. doi: 10.1016/j.sajb.2010.05.008

Cuvelier, M. E., Richard, H., Berset, C. (1996). Antioxidative activity and phenolic composition of pilot-plant and commercial extracts of sage and rosemary. J Am Oil Chem Soc, 73(5), 645-652. doi: 10.1007/BF02518121

Dean, E. W., Stark, D. D. (1920). A Convenient Method for the Determination of Water in Petroleum and Other Organic Emulsions. I Ind Eng Chem, 12(5), 486-490. doi: 10.1021/ie50125a025

Degenhardt, J., Köllner, T. G., Gershenzon, J. (2009). Monoterpene and sesquiterpene synthases and the origin of terpene skeletal diversity in plants. Phytochemistry, 70(15-16), 1621-1637. doi: 10.1016/j.phytochem.2009.07.030

Dorman, H. D., Deans, S. G. (2000). Antimicrobial agents from plants: antibacterial activity of plant volatile oils. J Appl Microbiol, $88(2)$, 308-316. doi: 10.1046/j.13652672.2000.00969.x

Džamić, A. M., Soković, M. D., Ristić, M. S., Grujić, S. M., Mileski, K. S., Marin, P. D. (2014). Chemical composition, antifungal and antioxidant activity of Pelargonium graveolens essential oil. J Appl Pharm Sci, 4(03), 001-005. doi: 10.7324/JAPS.2014.40301

Erdoğan, A. E., Everest, A. (2013). Antimikrobiyal ajan olarak bitki bileşenleri. Turkish Journal of Scientific Reviews, 6(2), 27-32. ISSN: 1308-0040, E-ISSN: 2146-0132

Fardhyanti, D. S., Sediawan, W. B., Hisyam, A. (2019). Kinetics of mace (Myristicae arillus) essential oil extraction using microwave assisted 
hydrodistillation: Effect of microwave power. Ind Crop and Prod, 131, 315-322. doi: 10.1016/j.indcrop.2019.01.067

Fayed, S. A. (2009). Antioxidant and anticancer activities of Citrus reticulate (Petitgrain Mandarin) and Pelargonium graveolens (Geranium) essential oils. Res J Agric Biol Sci, 5(5), 740-747.

Feglo, P., Sakyi, K. (2012). Bacterial contamination of street vending food in Kumasi, Ghana. Journal of Medical and Biomedical Sciences, 1(1), 1-8. ISSN: 2026-6294

Ghannadi, A., Bagherinejad, M. R., Abedi, D., Jalali, M., Absalan, B., Sadeghi, N. (2012). Antibacterial activity and composition of essential oils from Pelargonium graveolens L'Her and Vitex agnus-castus L. Iran J Microbiol, 4(4), 171.

Gomes, P. B., Mata, V. G., Rodrigues, A. E. (2007). Production of rose geranium oil using supercritical fluid extraction. J Supercrit Fluids, 41(1), 50-60. doi: 10.1016/j.supflu.2006.08.018

Guenther, E., Althausen, D. (1948). The essential oils (Vol. 1, p. 774). New York: Van Nostrand.

Hammer, K. A., Carson, C. F., Riley, T. V. (1999). Antimicrobial activity of essential oils and other plant extracts. J Appl Microbiol, 86 (6), 985-990. doi: 10.1046/j.1365-2672.1999.00780.x

Högnadóttir, Á., Rouseff, R. L. (2003). Identification of aroma active compounds in orange essence oil using gas chromatographyolfactometry and gas chromatography-mass spectrometry. J Chromatogr A, 998(1-2), 201-211. doi: 10.1016/S0021-9673(03)00524-7

Hsouna, A. B., Hamdi, N. (2012). Phytochemical composition and antimicrobial activities of the essential oils and organic extracts from Pelargonium graveolens growing in Tunisia. Lipids Health Dis, 11(1), 167. doi: 10.1186/1476-511X-11-167

Jirovetz, L., Eller, G., Buchbauer, G., Schmidt, E., Denkova, Z., Stoyanova, A., Geissler, M. (2006). Chemical composition, antimicrobial activities and odor descriptions of some essential oils with characteristic floral-rosy scent and of their principal aroma compounds. Recent Research Developments in Agronomy \& Horticulture, 2, 1-12.
Kaya, D., Ergönül, P. G. (2015). Uçucu yağlar elde etme yöntemleri. GIDA, 40(5), 303-312. doi: 10.15237 /gida.GD15014

Kurca, A., Arslan, E. (2008). Antioxidant capacity and total phenolic content of selected plants from Turkey. Int J of Food Sci Tech, 43(11), 2038-2046. doi: 10.1111/j.1365-2621.2008.01818.x

Kürekçi, C., Sakin, F. (2017). Uçucu Yağlar: Antimikrobiyal Açıdan Uçucu Yağlar: In-Vitro ve In-Vivo Çalışmalar. Turkize Klinikleri J Anim Nut \& Nutr Dis-Special Topics, 3(1), 15-20.

Lapczynski, A., Bhatia, S. P., Letizia, C. S., Api, A. M. (2008). Fragrance material review on dlcitronellol. Food Chem Toxicol, 46(11), S103-S109. doi: 10.1016/j.fct.2008.06.043

Meilgaard, M., Civille, G. V., Carr, B. T., (1999). Sensory Evaluation Techniques (3. bask1). CRC Press Taylor \& Francis Group, FL, ABD. 161-170. ISBN: 1420005561

Pandey, V., Patra, D. D. (2015). Crop productivity, aroma profile and antioxidant activity in Pelargonium graveolens L'Hér. under integrated supply of various organic and chemical fertilizers. Ind Crop Prod, 67, 257-263. doi: 10.1016/j.indcrop.2015.01.042

Peterson, A., Machmudah, S., Roy, B. C., Goto, M., Sasaki, M., Hirose, T. (2006). Extraction of essential oil from geranium (Pelargonium graveolens) with supercritical carbon dioxide. J Chem Technol \& Biotechnol: International Research in Process, Environmental \& Clean Technology, 81(2), 167-172. doi: $10.1002 /$ jctb.1375

Rahman, A. N. A., Mohamed, A. A. R., Mohammed, H. H., Elseddawy, N. M., Salem, G. A., El-Ghareeb, W. R. (2020). The ameliorative role of geranium (Pelargonium graveolens) essential oil against hepato-renal toxicity, immunosuppression, and oxidative stress of profenofos in common carp, Cyprinus carpio (L.). Aquaculture, 517, $734777 . \quad$ doi: 10.1016/j.aquaculture.2019.734777

Randhawa, M. A. (2006). The effect of dimethyl sulfoxide (DMSO) on the growth of dermatophytes. Nippon Ishinkin Gakkai Zasshi, 47(4), 313-318. doi: 10.3314/jjmm.47.313 
Ravindra, N. S., Kulkarni, R. N. (2015). Essential oil yield and quality in rose-scented geranium: Variation among clones and plant parts. Sci HorticAmsterdam, 184, 31-35. doi: 10.1016/j.scienta.2014.12.023

Re, R., Pellegrini, N., Proteggente, A., Pannala, A., Yang, M., Rice-Evans, C. (1999). Antioxidant activity applying an improved ABTS radical cation decolorization assay. Free Radical Bio Med, 26(910), 1231-1237. doi: 10.1016/S08915849(98)00315-3

Rosato, A., Vitali, C., De Laurentis, N., Armenise, D., Milillo, M. A. (2007). Antibacterial effect of some essential oils administered alone or in combination with Norfloxacin. Phytomedicine, 14(11), 727-732. doi: 10.1016/j.phymed.2007.01.005

Rosato, A., Maggi, F., Cianfaglione, K., Conti, F., Ciaschetti, G., Rakotosaona, R., Corbo, F. (2018). Chemical composition and antibacterial activity of seven uncommon essential oils. $J$ Essent oil Res, 30(4), 233-243. doi:10.1080/10412905. 2018.1442753

Saxena, G., Banerjee, S., Gupta, R., Laiq-urRahman, Tyagi, B. R., Kumar, S., Ramesh, S. (2004). Composition of the essential oil of a new isomenthone-rich variant of geranium obtained from geraniol-rich cultivar of Pelargonium species. $J$ Essent Oil Res, 16(2), 85-88. doi: 10.1080/10412905.2004.9698658

Singh, M., Singh, U. B., Ram, M., Yadav, A., Chanotiya, C. S. (2013). Biomass yield, essential oil yield and quality of geranium (Pelargonium graveolens L. Her.) as influenced by intercropping with garlic (Allium sativum L.) under subtropical and temperate climate of India. Ind Crop Prod, 46, 234-237. doi: 10.1016/j.indcrop.2013.01.032

Tournas, V. H., Heeres, J., Burgess, L. (2006). Moulds and yeasts in fruit salads and fruit juices. Food Microbiol, 23(7), 684-688. doi: 10.1016/j.fm.2006.01.003

Wells, R., Lis-Balchin, M. (2002). 22 Perfumery and cosmetic products utilising Geranium oil. Geranium and Pelargonium: History of Nomenclature, Usage and Cultivation, 247. ISBN: 9780203216538

Yamamoto, T., Matsuda, H., Utsumi, Y., Hagiwara, T., Kanisawa, T. (2002). Synthesis and odor of optically active rose oxide. Tetrabedron Lett, 43(50), 9077-9080. doi: 10.1016/S00404039(02)02311-0 